\title{
31. INTERSTITIAL WATER STUDIES, CENTRAL NORTH ATLANTIC ${ }^{1}$
}

\author{
Joris M. Gieskes, Kirk Johnston, and Marcus Boehm, Scripps Institution of Oceanography, \\ University of California at San Diego ${ }^{2}$
}

\begin{abstract}
Interstitial waters were collected at only two sites during Leg 82 , Sites 558 and 563 . Only very small changes in dissolved calcium and magnesium occur, presumably resulting from reactions in the underlying basement basalts. Dissolved strontium profiles indicate maxima, which can be understood in terms of carbonate recrystallization processes. Data on $\mathrm{Sr} / \mathrm{Ca}$ in carbonates cannot be used to estimate the extent of recrystallization that has occurred in these sediments.
\end{abstract}

\section{INTRODUCTION}

During Leg 82 interstitial waters were obtained at two drill sites-Holes 558 and 563 (Fig. 1). Shipboard analyses showed only very small changes in dissolved calcium and magnesium, but in such a situation the study of carbonate diagenesis may be of great interest. Matter et al. (1975) have shown that in carbonate sediments of the Shatsky Rise, where calcium and magnesium changes are also negligible, carbonate recrystallization reactions lead to the decrease in the $\mathrm{Sr} / \mathrm{Ca}$ ratio of carbonate and to an increase in the $\mathrm{Mg} / \mathrm{Ca}$ ratio. Baker et al. (1982), using experimentally determined distribution coefficients for strontium in carbonates, were able to predict these variations quite well. Similar observations were made by Elderfield et al. (1982) for carbonate sediments on the Ontong Java Plateau (DSDP Sites 288 and 289). In the present paper we present more extensive analyses of the interstitial water samples obtained during Leg 82 as well as some analysis of the solid carbonate chemistry.

\section{MATERIALS AND METHODS}

Interstitial water samples were obtained at Sites 558 and 563 using the routine shipboard sampling program, i.e., sampling at 50-m depth intervals at minimum.

Shipboard analyses included salinity, $\mathrm{pH}$, alkalinity, calcium, magnesium, and chloride content (Table 1). The acidified samples (alkalinity samples) were analyzed in our shore laboratory for dissolved silica, strontium, lithium, potassium, ammonia, and sulfate. Methods used have been discussed by Gieskes (1974), Gieskes and Lawrence (1976), and Gieskes et al. (1982).

Carbonate analyses (Table 2) were performed on whole sediment samples. These samples were dried at $105-110^{\circ} \mathrm{C}$, powdered, and then $0.2 \mathrm{~g}$ were dissolved in acetic acid-sodium acetate buffer at $\mathrm{pH} \sim 5.5$. Calcium analyses were carried out by titration (Gieskes, 1974), and magnesium and strontium were determined by means of atomic ab-

\footnotetext{
${ }^{1}$ Bougault, H., Cande, S. C., et al., Init. Repts. DSDP, 82: Washington (U.S. Govt. Printing Office)

2 Address: Scripps Institution of Oceanography, University of California at San Diego, La Jolla, California, 92093.
}

sorption techniques. Sea salt corrections were made by a separate chloride determination via a polarographic technique.

\section{RESULTS AND DISCUSSION}

\section{Interstitial Waters}

\section{Hole 558 (Fig. 2).}

Sediment accumulation rates in the upper $250-300 \mathrm{~m}$ averaged $\sim 17 \mathrm{~m} / \mathrm{Ma}$. At these relatively low accumulation rates sulfate depletions, as a result of sulfate reduction processes, are often minor. This explains the small downcore decrease in sulfate (Table 1).

Of interest are the calcium and magnesium concentration gradients. The gradients are very small but discernible. In Figure 2 the calcium and magnesium data indicate a generally good linear correlation with $\Delta \mathrm{Ca}$ / $\Delta \mathrm{Mg}=-1.25$. Just above basement, in a dolomitic chalk layer, an apparent reversal occurs in the gradients of calcium and magnesium. In our opinion, this represents a sample contaminated with seawater-additional reversals are observed for sulfate, strontium, and lithium. The latter two profiles, however, are not very reliable indicators of contamination, because maxima in the concentrations of these constituents are quite common at many other DSDP sites. Nonetheless, we are tempted to reject the bottom sample, and this would bring the albeit small increases in calcium and decreases in magnesium in accord with the general observation that in open-ocean sediments these gradients are caused by reactions in the basalts (McDuff, 1981; Gieskes and Lawrence, 1981; Gieskes, 1983).

Dissolved strontium shows a distinct maximum at $\sim 325 \mathrm{~m}$ (i.e., at the top of the zone of chalk formation). This can be attributed to the process of calcium carbonate recrystallization (Baker et al., 1981; Elderfield et al., 1982). Dissolved lithium shows only very slight increases and deserves no further comment. Downhole changes in potassium are within the limits of error, and thus no significant sink for this element exists either in the basalts or in the sediments at Site 558. Dissolved sili- 


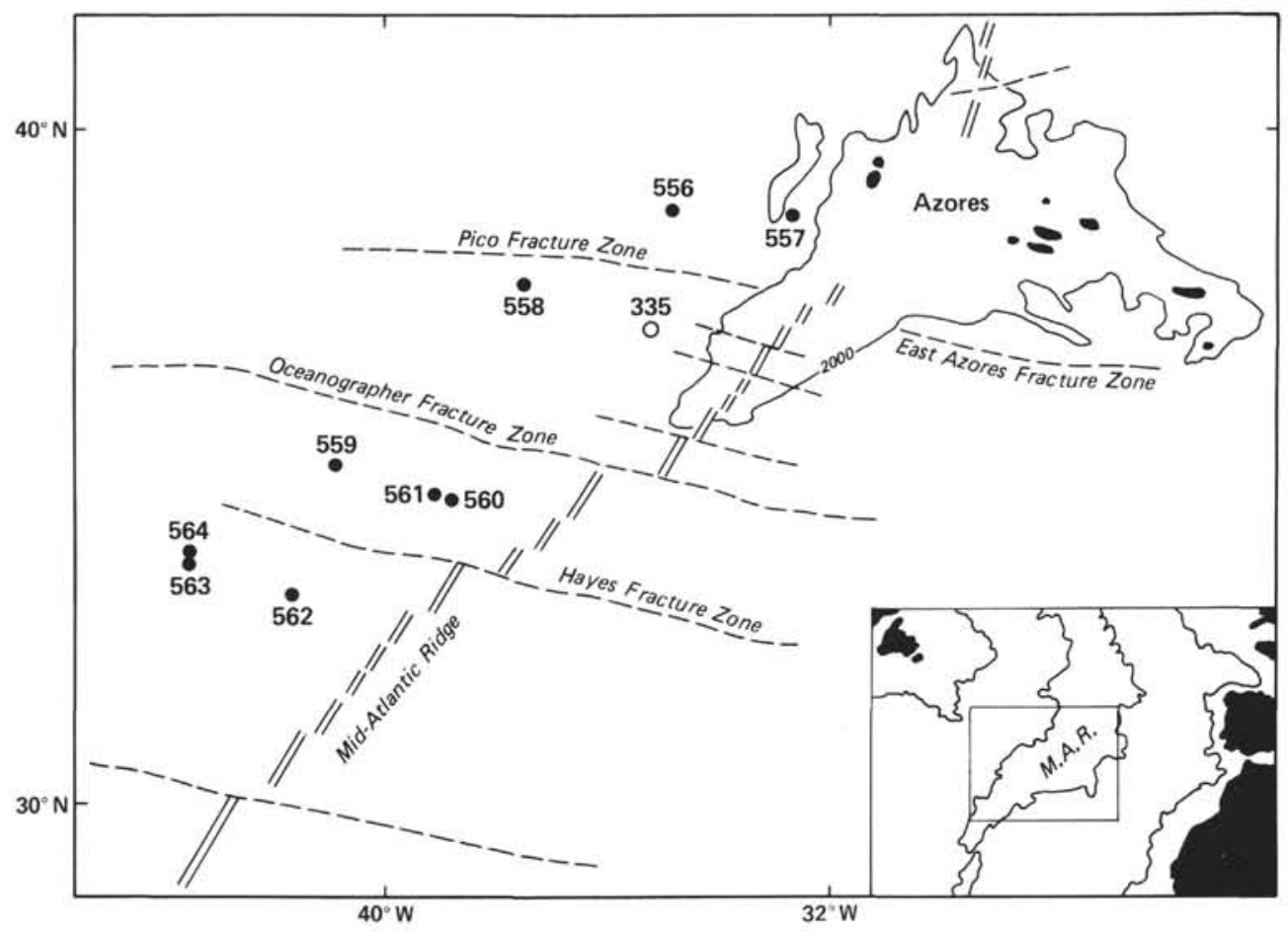

Figure 1. Map of study area, Leg 82 .

Table 1. Interstitial water chemistry, Leg 82 .

\begin{tabular}{|c|c|c|c|c|c|c|c|c|c|c|c|c|c|c|}
\hline Hole & $\begin{array}{c}\text { Core-Section } \\
\text { (interval in cm) }\end{array}$ & $\begin{array}{l}\text { Sub-bottom } \\
\text { depth } \\
\text { (m) }\end{array}$ & $\mathrm{pH}$ & $\begin{array}{l}\text { Alkalinity } \\
\left(\mathrm{meq} / \mathrm{dm}^{3}\right)\end{array}$ & $\begin{array}{l}\text { Salinity } \\
(\mathrm{g} / \mathrm{kg})\end{array}$ & $\underset{(\mathrm{mM})}{\mathrm{Ca}}$ & $\underset{(\mathrm{mM})}{\mathrm{Mg}}$ & $\underset{(\mathrm{g} / \mathrm{kg})}{\mathrm{Cl}}$ & $\underset{(\mu \mathrm{M})}{\mathrm{Sr}}$ & $\underset{(\mu \mathrm{M})}{\mathrm{Li}}$ & $\underset{(\mathrm{mM})}{\mathrm{K}}$ & $\begin{array}{l}\mathrm{SO}_{4} \\
(\mathrm{mM})\end{array}$ & $\begin{array}{l}\mathrm{NH}_{4} \\
(\mu \mathrm{M})\end{array}$ & $\underset{(\mu \mathrm{M})}{\mathrm{Si}}$ \\
\hline \multirow[t]{7}{*}{558} & $1-6,144-150$ & 168 & 7.36 & 2.99 & 37.6 & 11.0 & 50.7 & 19.48 & 323 & 41.7 & 11.5 & 25.8 & 0 & 187 \\
\hline & $6-6,140-150$ & 215 & 7.43 & 3.50 & 36.4 & 12.1 & 50.0 & 19.41 & 356 & 42.0 & 11.0 & & 0 & 603 \\
\hline & $8-3,110-120$ & 230 & 7.42 & 4.79 & 35.3 & 12.6 & 50.1 & 19.58 & 374 & 37.4 & 10.8 & 26.9 & 16.0 & 951 \\
\hline & $13-5,144-150$ & 280 & 7.31 & 3.92 & 36.8 & 13.4 & 50.2 & 19.62 & 400 & 36.9 & 10.4 & & 0 & 790 \\
\hline & $18-4,110-120$ & 325 & 7.34 & 4.03 & 35.3 & 14.1 & 48.3 & & 411 & 42.2 & 10.6 & 26.6 & 0 & 247 \\
\hline & $23-6,140-150$ & 377 & 7.39 & 3.27 & 35.3 & 15.2 & 47.8 & 19.04 & 305 & 47.1 & 10.2 & & 0 & 219 \\
\hline & $27-1,140-150$ & 407 & 7.13 & 3.00 & 36.2 & 12.1 & 53.3 & 19.31 & 104 & 31.3 & 9.8 & 28.1 & 0 & 62 \\
\hline \multirow[t]{3}{*}{$558 \mathrm{~A}$} & $1-7,12-19$ & 10 & 7.43 & 3.47 & 35.1 & 10.7 & 52.2 & 19.55 & 120 & 31.4 & 11.5 & 27.1 & 0 & 419 \\
\hline & $7-4,144-150$ & 56 & 7.44 & 3.19 & 36.3 & 10.7 & 51.4 & 19.62 & 256 & 41.8 & 11.8 & & 0 & 219 \\
\hline & $12-3,143-150$ & 82 & 7.42 & 3.20 & 36.1 & 11.0 & 51.1 & 19.65 & 282 & 36.6 & 10.5 & 26.4 & 15.7 & 157 \\
\hline \multirow[t]{5}{*}{563} & $1-2,140-150$ & 162 & 7.43 & 2.63 & 36.2 & 11.6 & 54.9 & 19.51 & 416 & 67.6 & 11.2 & 29.6 & 0 & 42 \\
\hline & $6-5,140-150$ & 212 & 7.47 & 2.54 & 35.7 & 11.6 & 53.3 & 19.71 & 406 & 62.4 & 10.8 & & 291.2 & 156 \\
\hline & $11-4,140-150$ & 260 & 7.52 & 2.77 & 36.4 & 12.0 & 50.6 & 19.61 & 417 & 67.8 & 10.5 & 25.3 & 146.0 & 235 \\
\hline & $16-6,140-150$ & 308 & 7.48 & 2.62 & 35.8 & 12.5 & 50.7 & 19.54 & 416 & 67.7 & 10.2 & & 114.5 & 203 \\
\hline & $21-6,140-150$ & 355 & 7.51 & 2.40 & 35.5 & 12.4 & 49.4 & 19.31 & 270 & 16.7 & 10.1 & 25.2 & 0 & 202 \\
\hline
\end{tabular}

Table 2. Carbonate chemistry, Site 558.

\begin{tabular}{lccc}
\hline Core-Section & $\begin{array}{c}\mathrm{CaCO}_{3} \\
(\%)\end{array}$ & $\begin{array}{c}\mathrm{Mg} / \mathrm{Ca} \\
\left(\times 10^{-4}\right)\end{array}$ & $\begin{array}{c}\mathrm{Sr} / \mathrm{Ca} \\
\left(\times 10^{-4}\right.\end{array}$ \\
\hline Hole 558 & & & \\
& & & \\
$1-6$ & 93 & 20.4 & 16.3 \\
$6-6$ & 89 & 8.4 & 19.5 \\
$8-3$ & 94 & 12.2 & 17.2 \\
$13-5$ & 89 & 19.5 & 16.2 \\
$18-4$ & 89 & 32.5 & 15.0 \\
$23-6$ & 87 & 33.7 & 15.3 \\
$27-1$ & 53.5 & 89.4 & 14.2
\end{tabular}

Hole 558A

\begin{tabular}{llrl}
$2-7$ & 89 & 9.4 & 19.2 \\
$7-4$ & 88 & 28.5 & 18.3 \\
$12-3$ & 93 & 28.5 & 17.5 \\
\hline
\end{tabular}

ca indicates the presence of biogenic silica at the base of Unit I as well as in the upper sediment layers.

\section{Hole 563 (Fig. 3)}

This site is characterized by relatively low sedimentation rates. Unfortunately, the upper $150 \mathrm{~m}$ were not sampled. Again, dissolved sulfate decreases slightly downhole.

The calcium increase with depth and the magnesium decrease with depth are barely significant. On the other hand, dissolved strontium and lithium do show maxi$\mathrm{ma}$. The former is related to the process of carbonate recrystallization-the ooze/chalk boundary is at the base of Unit I. The increase in lithium may be related to this process or to the release by biogenic silica (Gieskes, 1981), which appears enhanced in Unit II (cf., dissolved silica profile). 

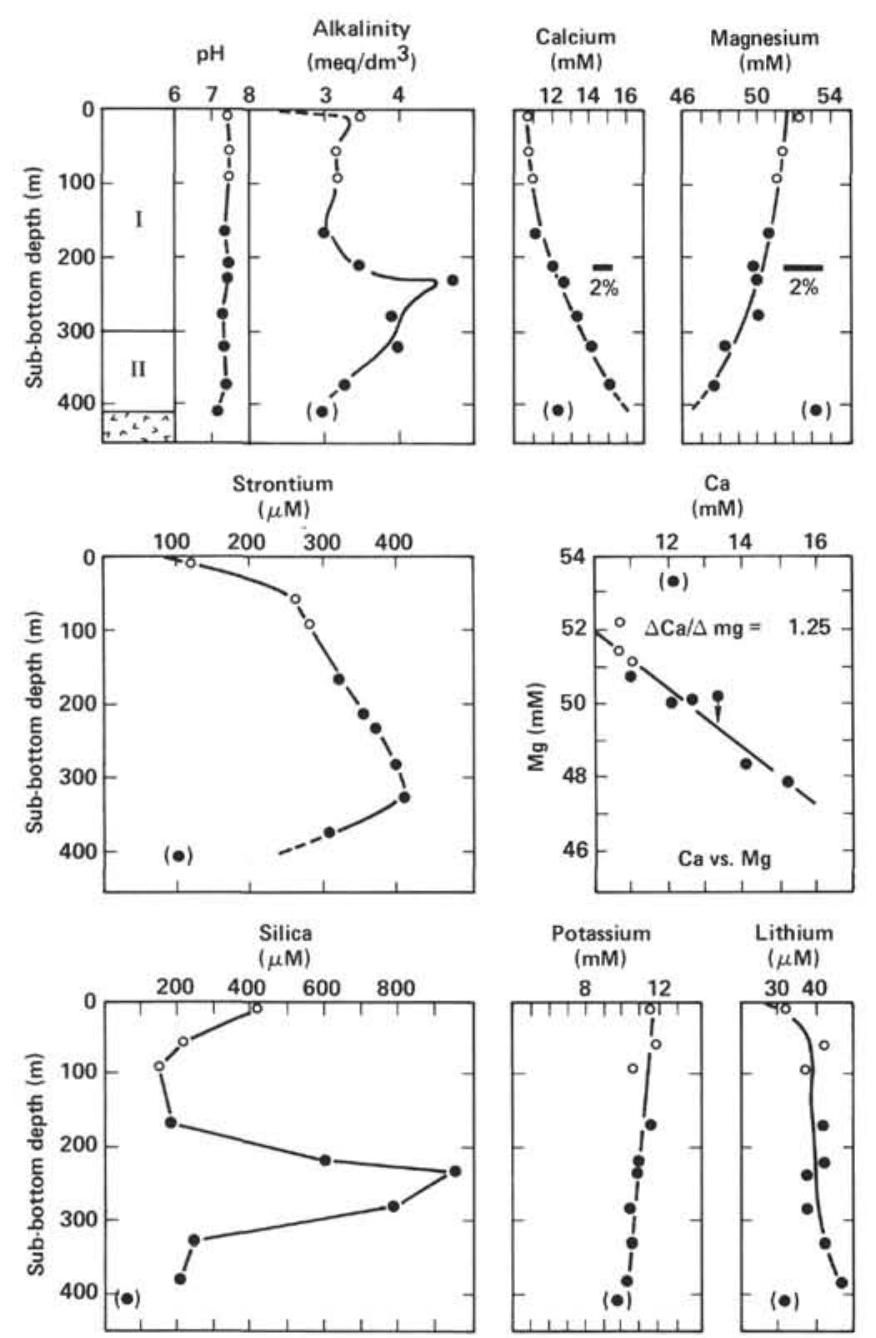

Figure 2. Interstitial water chemistry, Site 558. Lithology: I. Nannofossil ooze/chalk; siliceous nannofossil-foraminiferal ooze; foraminiferal-nannofossil ooze. II. Marly nannofossil chalk/limestone; dolomitic nannofossil chalk/limestone at base. Closed symbols, Hole 558; open symbols, Hole 558A.

\section{Carbonate Chemistry}

\section{Hole 558 (Fig. 4)}

Carbonate contents in this site are relatively constant throughout at $\sim 90 \%$, with the exception of the basal sediments.

$\mathrm{Mg} / \mathrm{Ca}$ ratios are variable, but the lowermost sample (Table 2) shows a rather high ratio. Recent experience has indicated, however, that exchangeable $\mathrm{Mg}^{++}$at low $\mathrm{CaCO}_{3}$ contents or the dissolution of magnesium-rich clays may lead to erroneously high $\mathrm{Mg} / \mathrm{Ca}$ ratios estimated by the present methodology. For these reasons $\mathrm{Mg} / \mathrm{Ca}$ ratios reported here must be considered to be preliminary in nature.

$\mathrm{Sr} / \mathrm{Ca}$ ratios are much less affected because interstitial water concentrations and exchangeable $\mathrm{Sr}^{++}$are very low compared to the contents in the carbonates. The data in Figure 4 demonstrate a gradual decrease in $\mathrm{Sr} / \mathrm{Ca}$, which can be understood in terms of carbonate recrystallization (Baker et al., 1982). The ratio decreases to about $14 \times 10^{-4}$. At the dissolved $\mathrm{Sr}^{++}$maximum,
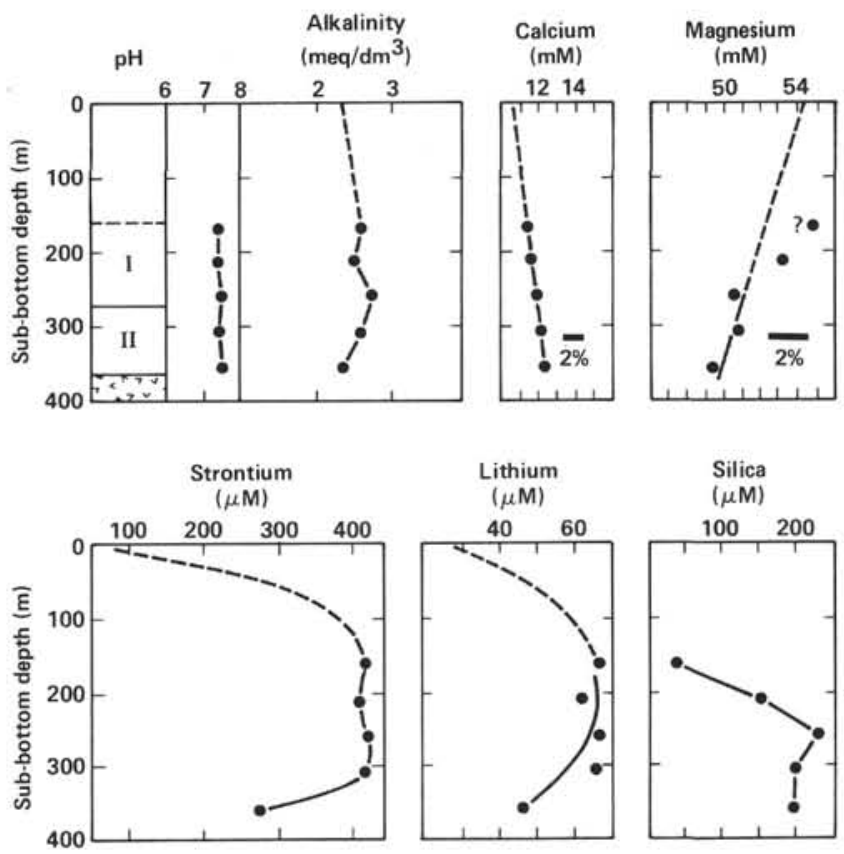

Figure 3. Interstitial water chemistry, Site 563. Lithology: I. Foraminiferal nannofossil ooze/chalk; nannofossil ooze. II. Chalks, dolomitic at base.
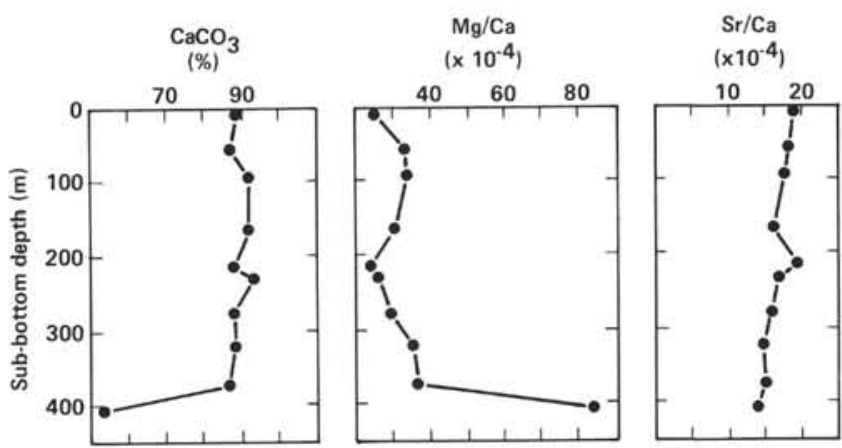

Figure 4. Carbonate chemistry, Hole 558A: $\mathrm{CaCO}_{3}(\%)$ and $\mathrm{Mg} / \mathrm{Ca}$ and $\mathrm{Sr} / \mathrm{Ca}$ (atomic ratios).

where the rate of crystallization is presumably at a maximum, one calculates a theoretical $\mathrm{Sr} / \mathrm{Ca}$ ratio of $(13 \pm 1)$ $\times 10^{-4}$ (i.e., close to the observed values). These data support the general contention that, at the level of the strontium maximum, carbonate recrystallization has been completed to large extent (Baker et al., 1982).

\section{CONCLUSIONS}

Interstitial waters sampled at Sites 558 and 563 indicate very small changes in calcium and magnesium with depth. The increase in calcium and decrease in magnesium are probably due to reactions taking place in the underlying basalts.

Carbonate recrystallization reactions are indicated by the occurrence of a strontium maximum near the ooze/ chalk boundary. Increases in lithium may be associated with this process, but may also result from the release of biogenic silica. 


\section{ACKNOWLEDGMENTS}

This research was supported by NSF grant OCE-80-23966 and OCE-82-18539. We thank the shipboard chemist, Mr. Don Marsee, for his diligent analyses in the laboratory of the Glomar Challenger. We thank Russ McDuff and Paul Baker for their reviews of this manuscript.

\section{REFERENCES}

Baker, P. A., Gieskes, J. M., and Elderfield, H., 1982. Diagenesis of carbonates in deep sea sediments: evidence from $\mathrm{Sr} / \mathrm{Ca}$ ratios and interstitial $\mathrm{Sr}^{2+}$ data. J. Sediment. Petrol., 52:71-82.

Elderfield, H., Gieskes, J. M., Baker, P. A., Oldfield, R. K., Hawkesworth, C. J., and Miller, R., $1982 .{ }^{87} \mathrm{Sr} /{ }^{86} \mathrm{Sr}$ and ${ }^{18} \mathrm{O} /{ }^{16} \mathrm{O}$ ratios, interstitial water chemistry and diagenesis in deep-sea carbonate sediments of the Ontong-Java Plateau. Geochim. Cosmochim. Acta, 46:2259-2268.

Gieskes, J. M., 1974. Interstitial water studies, Leg 25. In Simpson, E. S. W., Schlich, R., et al., Init. Repts. DSDP, 25: Washington (U.S. Govt. Printing Office); 361-394.

1981. Deep sea drilling interstitial water studies: implications for chemical alteration of the oceanic crust, Layers I and II. Spec. Publ., Soc. Econ. Paleontol. Mineral., 32:149-167.
1983. The chemistry of interstitial waters of deep sea sediments: interpretation of deep sea drilling data. In Riley, J. P., and Chester, R. (Eds.), Chemical Oceanography, 8:221-269.

Gieskes, J. M., Elderfield, H., Lawrence, J. R., Johnson, J., Meyers, B., and Campbell, A., 1982. Geochemistry of interstitial waters and sediments, Leg 64, Gulf of California. In Curray, J. R., Moore, D. G., et al., Init. Repts. DSDP, 64, Pt. 2: Washington (U.S. Govt. Printing Office), 675-694.

Gieskes, J. M., and Lawrence, J. R., 1976. Interstitial water studies, Leg 35. In Hollister, C. D., Craddock, C., et al., Init. Repts. $D S D P, 35$ : Washington (U.S. Govt. Printing Office), 407-424.

1981. Alteration of volcanic matter in deep sea sediments: evidence from the chemical composition of interstitial waters from deep sea drilling cores. Geochim. Cosmochim. Acta, 45:1687-1703.

McDuff, R. E., 1981. Major cation gradients in DSDP interstitial waters: the role of diffusive exchange between seawater and upper oceanic crust. Geochim. Cosmochim. Acta, 45:1705-1713.

Matter, A., Douglas, R. G., and Perch-Nielsen, K., 1975. Fossil preservation, geochemistry, and diagenesis, of pelagic carbonates from Shatsky Rise, northwest Pacific. In Larson, R. L., Moberly, R., et al., Init. Repts. DSDP, 32: Washington (U.S. Govt. Printing Office), 891-921.

Date of Initial Receipt: 26 July 1983

Date of Acceptance: 15 December 1983 